\title{
Order of amino acid inclusion in the diet of DeKalb White laying hens
}

\section{Ordem de inclusão de aminoácidos na dieta de poedeiras DeKalb White}

\author{
Danilo Vargas Gonçalves Vieira ${ }^{1 *}$; Thiago de Sousa Melo; \\ José Humberto Vilar da Silva ${ }^{3}$; Fernando Guilherme Perazzo Costa ${ }^{3}$; \\ Danilo Teixeira Cavalcante ${ }^{2}$; Matheus Ramalho de Lima ${ }^{4}$; Talita Pinheiro Bonaparte; \\ José Geraldo de Vargas Júnior ${ }^{6}$; Marilú Santos Sousa ${ }^{1}$; Ana Carolina Müller Conti ${ }^{1}$
}

\begin{abstract}
Three hundred and twenty-four DeKalb White laying hens aged 42 weeks were distributed in a completely randomised design with nine treatments and six replicates of six birds in each treatment. The experiment lasted 112 days. Diets were: $\mathrm{T}_{1}=16.02 \%$ crude protein $-\mathrm{CP}[\mathrm{Met}+\mathrm{Lys}+\mathrm{Thr}+\mathrm{Trp}+\mathrm{Val}] ; \mathrm{T}_{2}=14.02 \%$ $\mathrm{CP}[\mathrm{Met}+\mathrm{Lys}+\mathrm{Thr}+\mathrm{Trp}+\mathrm{Ile}+\mathrm{Val}] ; \mathrm{T}_{3}=14.02 \% \mathrm{CP}$ [no amino acid supplementation]; $\mathrm{T}_{4}=14.02 \%$ $\mathrm{CP}[\mathrm{Met}+\mathrm{Lys}+\mathrm{Thr}+\mathrm{Trp}] ; \mathrm{T}_{5}=14.02 \% \mathrm{CP}[\mathrm{Met}+\mathrm{Lys}+\mathrm{Thr}] ; \mathrm{T}_{6}=14.02 \% \mathrm{CP}[\mathrm{Met}] ; \mathrm{T}_{7}=14.02 \% \mathrm{CP}$ [Lys]; $\mathrm{T}_{8}=14.02 \% \mathrm{CP}[\mathrm{Thr}] ; \mathrm{T}_{9}=14.02 \% \mathrm{CP}$ [Trp]. Regarding the quality of the eggs, the percentage of yolk and albumen, shell thickness and Haugh unit were not affected by the different diets. The percentage of shell, specific gravity and albumen height showed significant differences. We found that supplementation of only one amino acid in the $\operatorname{diet}\left(\mathrm{T}_{7}, \mathrm{~T}_{8}\right.$ or $\left.\mathrm{T}_{9}\right)$, with the exception of methionine $\left(\mathrm{T}_{6}\right)$, worsened performance relative to the control. Supplementation of three amino acids (methionine, lysine and threonine; $\mathrm{T}_{5}$ ) or four amino acids (methionine, lysine, threonine and tryptophan; $\mathrm{T}_{4}$ ) worsened egg production and conversion per mass and per dozen eggs; however, feed intake and egg weight and mass were similar to the control treatment. When all amino acids (methionine, lysine, threonine, tryptophan, isoleucine and valine; $\mathrm{T}_{2}$ ) were supplemented performance was similar to the control treatment in all variables. Supplementation of methionine, lysine and threonine is essential for birds in the laying phase; however the addition of six essential amino acids (lysine, methionine, threonine, tryptophan, valine and isoleucine) to the diet of laying hens is important for a good productive performance comparable with the control treatment $T_{1}$. However, the inclusion of the latter two (isoleucine and valine) is justified only if the production cost is lower.
\end{abstract}

Key words: Egg quality. Laying hens. Limiting amino acids. Nitrogen excretion. Performance.

${ }^{1}$ Profs., Universidade Federal do Tocantins, Escola de Medicina Veterinária e Zootecnia, Colegiado de Zootecnia, Araguaína, TO, Brasil. E-mail: danilovargaszoo@mail.uft.edu.br; mariluzoo@hotmail.com; acmconti@hotmail.com

2 Discentes de Doutorado, Universidade Federal da Paraíba, Centro de Ciências Agrárias, Programa de Doutorado Integrado em Zootecnia, Areia, PB, Brasil. E-mail: thiagosoumelo@hotmail.com; danilo.zootec@hotmail.com

${ }^{3}$ Profs., Universidade Federal da Paraíba, Centro de Ciências Agrárias, Colegiado de Zootecnia, Areia, PB, Brasil. E-mail: vilardasiva@yahoo.com.br; perazoo63@gmail.com

${ }^{4}$ Prof., Universidade Federal do Sul da Bahia, Teixeira de Freitas, BA, Brasil. E-mail: mrlmatheus@gmail.com

5 Pós-Doutoranda, Universidade Federal do Espírito Santo, Centro de Ciências Agrárias, Alegre, ES, Brasil. E-mail: talitabonaparte@ gmail.com

${ }^{6}$ Prof., Universidade Federal do Espírito Santo, Centro de Ciências Agrárias, Colegiado de Zootecnia, Alegre, ES, Brasil. E-mail: josegeraldovargas@yahoo.com.br

* Author for correspondence 


\section{Resumo}

Trezentos e vinte e quatro galinhas poedeiras DeKalb White com idades de 42 semanas foram distribuídas em um delineamento experimental inteiramente casualizado, com nove tratamentos e seis repetições de seis aves em cada tratamento. $\mathrm{O}$ experimento teve duração de 112 dias. As dietas foram: $\mathrm{T}_{1}=16,02 \%$ PB $[$ Met + Lys + Thr + Trp + Val $] ; \mathrm{T}_{2}=14,02 \%$ PB $[$ Met + Lys + Thr + Trp + Ile + Val $] ; \mathrm{T}_{3}=14,02 \%$ de PB [sem suplementação de aminoácidos]; $\mathrm{T}_{4}=14,02 \% \mathrm{CP}$ [Met $+\mathrm{Lys}+\mathrm{Thr}+\mathrm{Trp}$ ]; $\mathrm{T}_{5}=14,02 \% \mathrm{CP}$ $[\mathrm{Met}+\mathrm{Lys}+\mathrm{Thr}] ; \mathrm{T}_{6}=14,02 \% \mathrm{CP}[\mathrm{Met}] ; \mathrm{T}_{7}=14,02 \% \mathrm{CP}[\mathrm{Lys}] ; \mathrm{T}_{8}=14,02 \% \mathrm{CP}[\mathrm{Thr}] ; \mathrm{T}_{9}=14,02 \%$ $\mathrm{CP}$ [Trp]. Em relação à qualidade dos ovos, a porcentagem de gema e albúmen, espessura de casca e a unidade Haugh não foram afetadas pelas dietas diferentes. A percentagem de casca, gravidade específica e altura do albúmen mostraram diferenças significativas. Verificou-se que a suplementação de apenas um aminoácido na dieta $\left(\mathrm{T}_{7} ; \mathrm{T}_{8}\right.$ ou $\left.\mathrm{T}_{9}\right)$, com a exceção de metionina $\left(\mathrm{T}_{6}\right)$, piorou o desempenho das aves em relação a aves que consumiram a dieta controle. A suplementação de três aminoácidos (metionina, lisina e treonina; $\mathrm{T}_{5}$ ) ou quatro aminoácidos (metionina, lisina, treonina e triptofano; $\mathrm{T}_{4}$ ) agravou a produção de ovos e conversão por massa e por dúzia de ovos; no entanto, o consumo de ração e peso dos ovos e massa de ovos, o desempenho foi semelhante ao tratamento controle $\mathrm{T}_{1}$. Quando todos os aminoácidos (metionina, lisina, treonina, triptofano, isoleucina e valina; $\mathrm{T}_{2}$ ) foram suplementados a dieta, o desempenho foi semelhante ao tratamento de controle em todas as variáveis. A suplementação de metionina, lisina e treonina é essencial para as aves na fase de colocação, no entanto, a adição de seis aminoácidos essenciais (lisina, metionina, treonina, triptofano, valina e isoleucina) à dieta de galinhas poedeiras é importante para um bom desempenho produtivo comparável com o tratamento controle. No entanto, a inclusão dos dois últimos (isoleucina e valina) só se justifica o custo de produção é menor.

Palavras-chave: Aminoácidos limitantes. Desempenho. Excreção de nitrogênio. Poedeiras comerciais. Qualidade dos ovos.

\section{Introduction}

The use of synthetic amino acids in the diet allows for improved efficiency in the use of dietary protein (SABINO et al., 2004), reducing the energy spent on the maintenance of the animal by decreasing the calorie gain generated from crude protein metabolism (LEESON; SUMMERS, 1997; SILVA et al., 2006; MATOS et al., 2011). Moreover, there is lower nitrogen output (KERR; EASTER, 1995; SABINO et al., 2004) and improved environmental impact (PAVAN et al., 2005) due to a reduction in the excretion of intact protein (COSTA et al., 2004).

The protein requirements of layer hens are conditioned mainly to the components of production, maintenance, growth of body tissues and level of feathers (FARIA; SANTOS, 2005). Layers depend on the daily ingestion of protein because their ability to store it is low. According to Patterson and Adrizal (2005), only $51.1 \%$ of the nitrogen ingested by birds is retained in the carcass.
Evaluating dietary protein reduction $(17.5,16.5$ and $15.5 \%$ crude protein) at three levels of energy intake $(2,700 ; 2,800$ and $2,900 \mathrm{kcal} / \mathrm{kg}$ diet $)$, Costa et al. (2004) showed that the best crude protein and metabolisable energy levels for Lohmann Brown layers of 43 to 55 weeks of age are respectively $17.50 \%$ and $2,900 \mathrm{kcal} / \mathrm{kg}$ for optimum weight and albumen percentage and $15.50 \%$ and $2,700 \mathrm{kcal} / \mathrm{kg}$ for optimum weight and shell percentage.

Working with Hisex White layers at 48 weeks of age receiving diets with four CP levels (12, 14, 16 and $18 \%$ ) and two lysine levels (0.85 and $1.00 \%)$, Silva et al. (2010) found that the use of a diet with $12 \%$ of $\mathrm{CP}$ supplemented with lysine does not compromise egg production. Egg weight, egg mass and percentage of albumen respond positively and linearly to increasing crude protein levels. Nitrogen balance is not modified by the dietary crude protein levels.

There are several strains of laying hens on the market, each of which have different levels of 
performance. Among other parameters posture, feed intake, and egg weight affect the requirements of laying hens, justifying the constant review of the animals' nutritional requirements. It is also essential to take into account factors such as climate variables to define the requirements of the birds.

The objective of this study is to analyse the order of importance of amino acids in the diet of DeKalb White layer hens when crude protein in the diets is reduced by two percentage points with supplementation of amino acids, and the effect of the supplemented amino acids on performance and egg quality.

\section{Material and Methods}

The experiment was conducted in the Poultry Laboratory of Núcleo de Pesquisa em Aves of Centro de Ciências Humanas, Sociais e Agrárias (CCHSA - Poultry Research Center of the Human, Social and Agragrian Sciences Department), campus III of Universidade Federal da Paraíba (PB), located in the municipality of Bananeiras, Paraíba, Brazil. This region is located at latitude $6^{\circ} 48^{\prime} 45^{\prime \prime} \mathrm{S}$, with an annual average precipitation of 1,200 $\mathrm{mm}$.

The experiment consisted of four 28-day experimental periods (112 days total). Three hundred and twenty-four Dekalb White hens were used at 32 weeks of age, in a completely randomised design, with nine treatments and six replications of six birds each. Experimental diets (Table 1) were formulated so as to meet the nutritional requirements for white hens, according to the recommendations of Rostagno et al. (2011). Birds were supplied with $115 \mathrm{~g}$ feed bird $^{-1}$ day $^{-1}$, with water at their disposal during the whole experimental period. Birds were fed the following diets: $\mathrm{T}_{1}=$ Control diet $16.02 \%$ crude protein - CP [suppl. ${ }^{7}$ Met + Lys + Thr + Trp + Val]; T $=$ Diet with $14.02 \% \mathrm{CP}$ [suppl. Met + Lys $+\mathrm{Thr}+\operatorname{Trp}$ + Ile + Val]; $\mathrm{T}_{3}=$ Diet with $14.02 \% \mathrm{CP}$ [no suppl. ${ }^{8}$ ]; $\mathrm{T}_{4}=$ Diet with $14.02 \%$ CP [suppl. Met + Lys $+\mathrm{Thr}$

\footnotetext{
${ }^{7}$ Supplementation of amino acids to the diet.

${ }^{8}$ Diet without supplementation.
}

+ Trp]; $\mathrm{T}_{5}=$ Diet with $14.02 \% \mathrm{CP}$ [suppl. Met + Lys $+\mathrm{Thr}$ ]; $\mathrm{T}_{6}=$ Diet with $14.02 \% \mathrm{CP}$ [suppl. Met]; $\mathrm{T}_{7}$ $=$ Diet with $14.02 \%$ CP [suppl. Lys]; $\mathrm{T}_{8}=$ Diet with $14.02 \%$ [suppl. Thr]; CP. $\mathrm{T}_{9}=$ Diet with $14.02 \% \mathrm{CP}$ [suppl. Trp]. The diet with supplementation of all amino acids met the recommendations for table birds in Brazil (ROSTAGNO et al., 2011).

The variables studied were feed intake ( $\mathrm{g}$ bird ${ }^{-}$ ${ }^{1}$ day $\left.^{-1}\right)$; egg production ( $\%$ bird $\left.^{-1} \mathrm{~d}^{-1}\right)$; body weight $(\mathrm{g})$; egg mass $(\mathrm{g})$; feed conversion per mass $(\mathrm{kg}$ $\left.\mathrm{kg}^{-1}\right)$; feed conversion per dozen eggs $\left(\mathrm{kg} \mathrm{dz}^{-1}\right)$; egg specific gravity $\left(\mathrm{g} \mathrm{cm}^{3(-1)}\right)$; shell thickness (mm); percentages of yolk, albumen and shell (\%); Haugh unit; and nitrogen balance.

Average egg specific gravity $\left(\mathrm{g} \mathrm{cm}^{3(-1)}\right)$ was measured by immersing all intact eggs in solutions of common salt with densities ranging from 1.0525 to $1.100 \mathrm{~g} \mathrm{~cm}^{3(-1)}$, at intervals of $0.0025 \mathrm{~g} \mathrm{~cm}^{3(-1)}$.

At the end of the 112-day experimental period, one bird of average weight for the treatment was selected from each experimental unit and housed in a metabolic cage. Two birds were housed in each compartment, totalling three repetitions per treatment with six birds.

A plastic-coated galvanised metal tray was placed below the floor of the cages for the collection of excreta. Cages were equipped with gutter-type feeders and drinkers. Feed was weighed and $2 \%$ of marker (ferric oxide) was added before it was supplied to the birds. Excreta were collected for three days, with two collections per day. At the end of the two-day period, the orts of the marked diet were weighed for the subsequent calculation of the balance of ingested nitrogen. Excreta were collected, and a representative sample from each experimental plot was collected. Samples were frozen at $-20^{\circ} \mathrm{C}$ for later analysis. Thawing of samples was performed in a natural shaded environment.

The nitrogen content of the experimental diets and excreta was quantified in order to calculate the nitrogen balance. The total nitrogen of samples was determined by the Micro Kjeldahl method. Analyses 
followed the recommendations of Silva and Queiroz (2006). The amount of consumed and excreted nitrogen was calculated based on the feed intake and amount of excreta produced in the evaluation period, respectively. The nitrogen retention was calculated as the difference between the intake and the excreta and expressed as the percentage ratio of nitrogen retained by the bird.

Table 1. Nutritional and chemical composition of experimental diets for commercial layers ${ }^{1}$.

\begin{tabular}{|c|c|c|c|c|c|c|c|c|c|}
\hline Ingredients & $\mathrm{T}_{1}$ & $\mathrm{~T}_{2}$ & $\mathrm{~T}_{3}$ & $\mathrm{~T}_{4}$ & $\mathrm{~T}_{5}$ & $\mathrm{~T}_{6}$ & $\mathrm{~T}_{7}$ & $\mathrm{~T}_{8}$ & $\mathrm{~T}_{9}$ \\
\hline Corn & 61.358 & 68.417 & 67.261 & 67.970 & 67.886 & 67.556 & 67.322 & 67.389 & 67.327 \\
\hline Soybean meal & 24.083 & 17.427 & 19.283 & 17.977 & 18.106 & 18.831 & 18.857 & 19.068 & 19.206 \\
\hline Limestone & 9.255 & 9.255 & 9.256 & 9.255 & 9.255 & 9.256 & 9.255 & 9.256 & 9.256 \\
\hline Soybean oil & 2.990 & 1.691 & 2.175 & 1.887 & 1.921 & 2.009 & 2.133 & 2.147 & 2.149 \\
\hline Dicalcium phosphate & 1.087 & 1.143 & 1.125 & 1.138 & 1.137 & 1.129 & 1.310 & 1.127 & 1.126 \\
\hline Common salt & 0.506 & 0.506 & 0.505 & 0.505 & 0.505 & 0.505 & 0.505 & 0.505 & 0.505 \\
\hline DL-methionine & 0.262 & 0.318 & --- & 0.312 & 0.311 & 0.304 & --- & --- & --- \\
\hline L-isoleucine & --- & 0.093 & --- & --- & --- & --- & --- & --- & --- \\
\hline L-lysine HCL & 0.052 & 0.254 & --- & 0.263 & 0.232 & --- & 0.209 & --- & --- \\
\hline L-threonine & 0.047 & 0.134 & --- & 0.126 & 0.125 & --- & --- & 0.111 & --- \\
\hline L-tryptophan & 0.008 & 0.044 & --- & 0.041 & --- & --- & --- & --- & 0.034 \\
\hline L-valine & 0.061 & 0.170 & --- & --- & --- & --- & --- & --- & --- \\
\hline Potassium carbonate & --- & 0.259 & 0.107 & 0.236 & 0.232 & 0.120 & 0.120 & 0.113 & 0.109 \\
\hline Choline chloride $60 \%$ & 0.100 & 0.100 & 0.100 & 0.100 & 0.100 & 0.100 & 0.100 & 0.100 & 0.10 \\
\hline Vitamin premix ${ }^{2}$ & 0.100 & 0.100 & 0.100 & 0.100 & 0.100 & 0.100 & 0.100 & 0.100 & 0.100 \\
\hline Mineral premix ${ }^{3}$ & 0.075 & 0.075 & 0.075 & 0.075 & 0.075 & 0.075 & 0.075 & 0.075 & 0.075 \\
\hline Antioxidant & 0.010 & 0.010 & 0.010 & 0.010 & 0.010 & 0.010 & 0.010 & 0.010 & 0.010 \\
\hline Total & 100.0 & 100.0 & 100.0 & 100.0 & 100.0 & 100.0 & 100.0 & 100.0 & 100.0 \\
\hline & \multicolumn{9}{|c|}{ Chemical composition ${ }^{4}$} \\
\hline Crude protein ${ }^{5}$ & 16.02 & 14.02 & 14.02 & 14.02 & 14.02 & 14.02 & 14.02 & 14.02 & 14.02 \\
\hline Metabolizable energy $^{6}$ & 2.900 & 2.900 & 2.900 & 2.900 & 2.900 & 2.900 & 2.900 & 2.900 & 2.900 \\
\hline Arginine $^{5}$ & 0.927 & 0.785 & 0.840 & 0.801 & 0.804 & 0.826 & 0.827 & 0.833 & 0.837 \\
\hline Phe + tyrosine $e^{5}$ & 1.254 & 1.046 & 1.109 & 1.065 & 1.069 & 1.094 & 1.094 & 1.102 & 1.106 \\
\hline Isoleucine $^{5}$ & 0.609 & 0.591 & 0.531 & 0.508 & 0.510 & 0.523 & 0.523 & 0.527 & 0.530 \\
\hline Leucine $^{5}$ & 1.320 & 1.171 & 1.220 & 1.186 & 1.188 & 1.208 & 1.208 & 1.214 & 1.218 \\
\hline Lysine $^{5}$ & 0.777 & 0.777 & 0.623 & 0.777 & 0.777 & 0.612 & 0.770 & 0.618 & 0.621 \\
\hline Methionine + cistine $^{5}$ & 0.707 & 0.707 & 0.413 & 0.707 & 0.707 & 0.707 & 0.408 & 0.410 & 0.412 \\
\hline Threonine $^{5}$ & 0.591 & 0.591 & 0.484 & 0.591 & 0.591 & 0.478 & 0.478 & 0.591 & 0.483 \\
\hline Tryptophan $^{5}$ & 0.179 & 0.179 & 0.145 & 0.179 & 0.139 & 0.143 & 0.143 & 0.144 & 0.179 \\
\hline Valine $^{5}$ & 0.738 & 0.738 & 0.601 & 0.579 & 0.580 & 0.593 & 0.594 & 0.598 & 0.600 \\
\hline Calcium $^{5}$ & 3.900 & 3.900 & 3.900 & 3.900 & 3.900 & 3.900 & 3.900 & 3.900 & 3.900 \\
\hline Choline $^{5}$ & 0.360 & 0.400 & 0.351 & 0.397 & 0.396 & 0.351 & 0.392 & 0.351 & 0.351 \\
\hline Available phosphorus ${ }^{5}$ & 0.291 & 0.291 & 0.291 & 0.291 & 0.291 & 0.291 & 0.291 & 0.291 & 0.291 \\
\hline Potassium $^{5}$ & 0.618 & 0.662 & 0.608 & 0.658 & 0.658 & 0.608 & 0.653 & 0.608 & 0.608 \\
\hline Sodium $^{5}$ & 0.218 & 0.218 & 0.218 & 0.218 & 0.218 & 0.218 & 0.218 & 0.218 & 0.218 \\
\hline Electrolytic balance $^{7}$ & 151.3 & 151.3 & 151.3 & 151.3 & 151.3 & 151.3 & 151.3 & 151.3 & 151.3 \\
\hline
\end{tabular}

${ }^{1}$ Recommendation of Rostagno et al. (2011). ${ }^{2}$ Composition $\mathrm{kg}^{-1}$ product: Vit. A - 12,000,000 IU; Vit. D - 3,600,000 IU; Vit. B - 2.5 g; Vit. B2 - 8 g; Vit. B - 3.0 g; Pantothenic acid - 12 g; Biotin - 0.2 g; vit. K - 3.0 g; Folic acid - 3.5 g; Nicotinic acid - 40 g; vit. B12 - 20 mg; Se - 0.13 g; Excipient q.s. - 1,000 g. ${ }^{3}$ Composition kg ${ }^{-1}$ of product: Mn - 160 g; Fe - 100 g; Zn - 100 g; Cu - 20 g; Co - 2 g; I - 2 g. Excipient q.s. - 1,000 g. 4 - Formulations in digestible amino acids. 5 - Expressed in percentage (\%). 6 - Expressed in kcal $\mathrm{kg}^{-1}$ diet. 7 - Expressed in $\mathrm{mEq} \mathrm{kg}^{-1}$ diet. 
The temperature and humidity in the shed was measured using a digital thermo-hygrometer and recorded throughout experimental period. Bird mortality was measured and corrected according to Sakomura and Rostagno (2007) for the variables analysed.

The data collected were subjected to an errornormality test (Shapiro-Wilk). All data showed normal error distribution $(\mathrm{P}>0.05)$, and therefore we could perform a variance analysis. Differences between treatments were investigated using a Student Newman Keuls test at 5\% probability.

\section{Results and Discussion}

The average temperature and humidity recorded $\left(25.7^{\circ} \mathrm{C}\right.$ and $62.65 \%$, respectively) were within the comfort range for adult birds. However, maximum temperatures at around $32.1^{\circ} \mathrm{C}$ and maximum (90.8\%) and minimum (42.2\%) humidity values outside the comfort limit for birds were observed.

Comfortable conditions for adult birds consist of temperatures between 15 and $28^{\circ} \mathrm{C}$ and relative humidity between 50 and $70 \%$. These conditions rarely occur in Brazil because of its geographical location with most of the country south of latitude $30^{\circ}$ (TINOCO, 2004).

However, these temperatures did not affect bird performance, as the maximum was recorded in the afternoon, when the humidity was low, which favoured heat loss by birds. In hot environments birds tend to reach thermal balance by utilizing latent mechanisms of thermal transfer i.e. evaporation through breathing (SILVA et al., 2008). This mechanism of heat loss is more efficient in hot environments as it does not depend on the temperature gradient between animal and environment, and its efficiency is boosted when the relative air humidity is low - because the amount of water vapour in the atmosphere is low, heat transfer through this mechanism is facilitated (MAIA et al., 2005).

We observed that the control diet, with $16.02 \%$ crude protein $\left(\mathrm{T}_{1}\right)$; the diet with $14.02 \%$ crude protein plus supplementation of all amino acids $\left(\mathrm{T}_{2}\right)$; the diet with supplementation of methionine, lysine, threonine and tryptophan $\left(\mathrm{T}_{4}\right)$; the diet with supplementation of methionine, lysine and threonine $\left(\mathrm{T}_{5}\right)$; and the diet with supplementation of methionine $\left(\mathrm{T}_{6}\right)$ presented similar feed intake (Table 2).

Table 2. Feed intake (FI), egg production (EP) and egg weight (EW) of white hens fed diets with levels of protein reduction and amino acid supplementation.

\begin{tabular}{|c|c|c|c|}
\hline Treatments & FI $\left(\right.$ g bird $^{-1}$ day $\left.^{-1}\right)$ & EP $\left(\%\right.$ bird $^{-1}$ day $\left.^{-1}\right)$ & EW $\left(\right.$ g egg $\left.^{-1}\right)$ \\
\hline $\mathrm{T}_{1}-16.02 \% \mathrm{CP}+\mathrm{Met}+\mathrm{Lys}+\mathrm{Thr}+\mathrm{Trp}+\mathrm{Val}$ & $105.27^{\mathrm{a}}$ & $86.87^{\mathrm{a}}$ & $64.61^{\mathrm{a}}$ \\
\hline $\mathrm{T}_{2}-14.02 \% \mathrm{CP}+\mathrm{Met}+\mathrm{Lys}+\mathrm{Thr}+\mathrm{Trp}+\mathrm{Ile}+\mathrm{Val}$ & $104.46^{\mathrm{a}}$ & $84.59^{\mathrm{ab}}$ & $64.08^{\mathrm{a}}$ \\
\hline $\mathrm{T}_{3}-14.02 \% \mathrm{CP}$ - no supplementation of amino acids & $97.30^{\text {cd }}$ & $67.61^{\mathrm{f}}$ & $59.58^{\mathrm{b}}$ \\
\hline $\mathrm{T}_{4}-14.02 \% \mathrm{CP}+\mathrm{Met}+\mathrm{Lys}+\mathrm{Thr}+\mathrm{Trp}$ & $104.46^{\mathrm{a}}$ & $82.30^{\mathrm{bc}}$ & $65.69^{\mathrm{a}}$ \\
\hline $\mathrm{T}_{5}-14.02 \% \mathrm{CP}+\mathrm{Met}+\mathrm{Lys}+\mathrm{Thr}$ & $104.13^{\mathrm{a}}$ & $81.45^{\mathrm{c}}$ & $64.47^{\mathrm{a}}$ \\
\hline $\mathrm{T}_{6}-14.02 \% \mathrm{CP}+\mathrm{Met}$ & $102.72^{\mathrm{ab}}$ & $81.32^{\mathrm{c}}$ & $63.30^{\mathrm{a}}$ \\
\hline $\mathrm{T}_{7}^{6}-14.02 \% \mathrm{CP}+$ Lys & $95.82^{\mathrm{d}}$ & $77.62^{\mathrm{d}}$ & $58.08^{\mathrm{bc}}$ \\
\hline $\mathrm{T}_{8}-14.02 \% \mathrm{CP}+\mathrm{Thr}$ & $96.83^{\mathrm{d}}$ & $72.23^{\mathrm{e}}$ & $58.07^{\mathrm{bc}}$ \\
\hline $\mathrm{T}_{9}^{8}-14.02 \% \mathrm{CP}+\mathrm{Trp}$ & $99.71^{\mathrm{c}}$ & $72.03^{\mathrm{e}}$ & $60.04^{\mathrm{b}}$ \\
\hline Probability & 0.001 & 0.001 & 0.001 \\
\hline CV (\%) & 3.73 & 3.20 & 3.59 \\
\hline $\mathrm{N}$ & 54 & 54 & 54 \\
\hline Mean & 101.79 & 78.45 & 61.99 \\
\hline STD & 3.778 & 6.507 & 3.022 \\
\hline
\end{tabular}

a,b Means followed by different lowercase letters in the column are significant by the SNK test; CV = coefficient of variation. Source of the author. N - Total number of data. STD - Standard deviation. 
The results of these authors (SILVA et al., 2006, 2010) were superior to those found in the present research for birds consuming diets containing $14.02 \%$ crude protein without supplementation of amino acids $\left(\mathrm{T}_{3}\right)$ or with supplementation of only one amino acid - lysine $\left(\mathrm{T}_{7}\right)$, threonine $\left(\mathrm{T}_{8}\right)$, or tryptophan $\left(\mathrm{T}_{9}\right)$. However, this superiority is because Silva et al. supplemented the diets with lysine and methionine (SILVA et al., 2006) and all other amino acids (SILVA et al., 2010). Thus, supplementing only one amino acid does not bring any advantage to performance. Nevertheless, supplementation of only methionine $\left(\mathrm{T}_{6}\right)$ gave similar performance to control $\left(\mathrm{T}_{1}\right)$ for the variables feed intake and egg weight (Table 2).

The decrease in feed intake for the diets with supplementation of only one amino acid (lysine $\left(\mathrm{T}_{7}\right)$; threonine $\left(\mathrm{T}_{8}\right)$; and tryptophan $\left(\mathrm{T}_{9}\right)$ is because the protein requirements for layer hens are conditioned mainly to the components of production and egg weight (FARIA; SANTOS, 2005) and depend on the daily ingestion of protein (PATTERSON; ADRIZAL, 2005). Since birds had lower production and egg weight in these treatments due to the reduction in protein and limitation of some amino acids, the decrease in intake was conditioned to the lower requirement for the quantity and size of eggs produced (Table 2).

This behaviour pattern was also found by Silva et al. (2006). They compared the performance of white layers fed three levels of crude protein $(16.5,15.2$ and $14 \%$ ) and observed a reduction in performance when birds were fed diets containing the lowest protein levels without supplementation of amino acids or with supplementation of lysine only.

Feed intake in birds fed on low protein diets was discussed by Harper, Benevenga and Wohlhueter (1970) and Bertechini (2006). The reduction in feed intake is due to changes in the profile of plasma amino acids, leading to activation of the mechanisms of appetite regulation. This represents an attempt by the organism to decrease the deleterious effects of the imbalanced diet. Therefore, in the diets where the birds did not present a difference in feed intake $\left(\mathrm{T}_{1}, \mathrm{~T}_{2}, \mathrm{~T}_{4}, \mathrm{~T}_{5}\right.$ and $\left.\mathrm{T}_{6}\right)$ the amino acids were shown to be within the ratio proposed by Rostagno et al. (2011) i.e. there was no imbalance caused by excess amino acids. The intake of birds receiving the diet with methionine supplementation only $\left(\mathrm{T}_{6}\right)$ was similar to control however, because in this treatment the birds presented similar weight (Table 2), egg mass and conversion per egg mass to the control (Table 3).

Still concerning production and egg weight, when there was supplementation of methionine, lysine, threonine and tryptophan $\left(\mathrm{T}_{4}\right)$; methionine, lysine and threonine $\left(\mathrm{T}_{5}\right)$; or methionine $\left(\mathrm{T}_{6}\right)$, the results were inferior to control treatment only for egg production. Egg weight in turn was similar to control (Table 3).

The similarity in egg weight is because of supplementation of methionine in the $\operatorname{diets}\left(\mathrm{T}_{1}\right.$, $\mathrm{T}_{2}, \mathrm{~T}_{4}, \mathrm{~T}_{5}$ and $\mathrm{T}_{6}$ ), which is known to be related to increased egg weight. These results were also similar to those of many authors (MENDONÇA JÚNIOR; LIMA, 1999; COSTA et al., 2004; SILVA et al., 2006). However, Silva et al. (2010) demonstrate that there is reduction in egg weight even with supplementation of methionine, but these authors worked with older requirements (ROSTAGNO et al., 2000) and animals of more advanced breeding.

Egg production and egg weight of birds fed the diets containing $14.02 \%$ crude protein without amino acid supplementation $\left(\mathrm{T}_{3}\right)$ or with supplementation of lysine $\left(\mathrm{T}_{7}\right)$,threonine $\left(\mathrm{T}_{8}\right)$, or tryptophan $\left(\mathrm{T}_{9}\right)$ only were inferior to the other treatments. In other words, supplementing diets with only these single amino acids affects productive performance. However if only egg production is compared, similar production was obtained as for treatment $\left(\mathrm{T}_{2}\right)$ supplemented with all amino acids (Met, Lys, Thr, Trp, Val and Ile). Maintenance of egg weight makes methionine inclusion necessary in the diets. However, this amino acids supplement alone is not able to maintain egg 
production and therefore the other amino acids (Lys, the inclusion of the last two (isoleucine and valine) Thr, Trp, Val and Ile) should be included. However, is justified only when production costs are lower.

Table 3. Egg mass (EM), conversion per mass (CEM) and per dozen eggs (CDZ) of white hens fed diets with levels of protein reduction and amino acid supplementation.

\begin{tabular}{|c|c|c|c|}
\hline Treatments & $\begin{array}{c}\text { EM } \\
\left(\mathrm{g} \mathrm{bird}^{-1} \text { day }^{-1}\right)\end{array}$ & $\begin{array}{c}\mathrm{CEM} \\
\left(\mathrm{kg} \mathrm{kg}^{-1}\right)\end{array}$ & $\begin{array}{c}\mathrm{CDZ} \\
\left(\mathrm{kg} \mathrm{dz}^{-1}\right)\end{array}$ \\
\hline $\mathrm{T}_{1}-16.02 \% \mathrm{CP}+\mathrm{Met}+\mathrm{Lys}+\mathrm{Thr}+\mathrm{Trp}+\mathrm{Val}$ & $55.9^{\mathrm{a}}$ & $1.85^{\mathrm{b}}$ & $1.45^{\mathrm{d}}$ \\
\hline $\mathrm{T}_{2}-14.02 \% \mathrm{CP}+\mathrm{Met}+\mathrm{Lys}+\mathrm{Thr}+\mathrm{Trp}+\mathrm{Ile}+\mathrm{Val}$ & $53.8^{\mathrm{a}}$ & $1.90^{\mathrm{b}}$ & $1.49^{\mathrm{cd}}$ \\
\hline $\mathrm{T}_{3}-14.02 \% \mathrm{CP}-$ no supplementation of amino acids & $40.1^{\mathrm{c}}$ & $2.40^{\mathrm{a}}$ & $1.72^{\mathrm{a}}$ \\
\hline $\mathrm{T}_{4}-14.02 \% \mathrm{CP}+\mathrm{Met}+\mathrm{Lys}+\mathrm{Thr}+\operatorname{Trp}$ & $53.8^{\mathrm{a}}$ & $1.94^{\mathrm{b}}$ & $1.52^{\mathrm{bcd}}$ \\
\hline $\mathrm{T}_{5}-14.02 \% \mathrm{CP}+\mathrm{Met}+$ Lys $+\mathrm{Thr}$ & $53.0^{\mathrm{a}}$ & $1.95^{\mathrm{b}}$ & $1.52^{\mathrm{bcd}}$ \\
\hline $\mathrm{T}_{6}-14.02 \% \mathrm{CP}+\mathrm{Met}$ & $52.8^{\mathrm{a}}$ & $2.00^{\mathrm{b}}$ & $1.54^{\mathrm{bcd}}$ \\
\hline $\mathrm{T}_{7}-14.02 \% \mathrm{CP}+$ Lys & $45.5^{\mathrm{b}}$ & $2.10^{\mathrm{b}}$ & $1.49^{\mathrm{cd}}$ \\
\hline $\mathrm{T}_{8}-14.02 \% \mathrm{CP}+\mathrm{Thr}$ & $41.4^{\mathrm{c}}$ & $2.46^{\mathrm{a}}$ & $1.67^{\mathrm{abc}}$ \\
\hline $\mathrm{T}_{9}-14.02 \% \mathrm{CP}+\mathrm{Trp}$ & $43.0^{\mathrm{bc}}$ & $2.39^{\mathrm{a}}$ & $1.71^{\mathrm{a}}$ \\
\hline Probability & 0.001 & 0.001 & 0.001 \\
\hline CV $(\%)$ & 4.50 & 6.32 & 5.56 \\
\hline $\mathrm{N}$ & 54 & 54 & 54 \\
\hline Mean & 48.81 & 2.11 & 1.57 \\
\hline STD & 6.215 & 0.241 & 0.103 \\
\hline
\end{tabular}

${ }^{\mathrm{a}, \mathrm{b}}$ Means followed by different lowercase letters in the column are significant by the SNK test; CV = coefficient of variation. Source of the author. N - Total number of data. STD - Standard deviation.

Egg mass and conversion per mass and per dozen eggs were significantly affected $(\mathrm{P}=0.001)$ by the different diets. We observed that egg masses were equal (Table 3 ) for the birds consuming the diet with $16.0 \%$ crude protein $\left(\mathrm{T}_{1}\right)$ and diets containing $14.02 \%$ protein with the addition of methionine, lysine, threonine, tryptophan, isoleucine and valine $\left(\mathrm{T}_{2}\right)$; lysine, threonine and tryptophan $\left(\mathrm{T}_{4}\right)$; lysine and threonine $\left(\mathrm{T}_{5}\right)$; and methionine $\left(\mathrm{T}_{6}\right)$. The same behaviour was verified for egg weight (Table 2). However, production did not present this behaviour (Table 2), as it is the product of weight and egg production. The effect observed for egg mass is due to the inclusion of methionine in the diets (Table 3 ) and because amino acids are related to increase in egg weight.

These results were also verified by Costa et al. (2004), who supplied reduced crude protein
(17.5, 16.5 and 15.5\%) supplemented with only lysine and methionine; and Silva et al. (2006), who supplied reduced crude protein at 16.5, 15.2 and $14 \%$ supplemented with methionine or lysine or both. Silva et al. (2010), however, reduced the crude protein $(18,16,14$ and 12\%) and observed a decrease in egg mass. Rombola et al. (2004) evaluated four crude protein levels $(12,14,16$ and $18 \%$ ) in layers at 49 to 56 weeks of age and verified that the egg mass of birds fed a $12 \%$ crude protein diet was inferior to that of birds fed diets of 16 and $18 \%$ crude protein.

Conversion per egg mass (Table 3) of birds receiving $16.2 \%$ crude protein diets $\left(\mathrm{T}_{1}\right)$; and diets containing $14.02 \%$ crude protein with addition of methionine, lysine, threonine, tryptophan, isoleucine and valine $\left(\mathrm{T}_{2}\right)$; lysine, threonine and tryptophan $\left(\mathrm{T}_{4}\right)$; lysine and threonine $\left(\mathrm{T}_{5}\right)$; methionine $\left(\mathrm{T}_{6}\right)$; and 
lysine $\left(\mathrm{T}_{7}\right)$ showed similar performance.

These data are similar to those published by Costa et al. (2004), Silva et al. (2006) and Silva et al. (2010), wherein the authors do not observe any worsening in conversion on reduction of protein and supplementation of amino acids in the diet.

Costa et al. (2004) worked with reductions of 17.5 to $15.5 \%$ crude protein; in other words, above the levels used in the present study. Silva et al. (2006, 2010 ) in turn worked with greater reductions i.e. the data of the present study corroborate the data of Silva et al. (2006, 2010), indicating that a reduction of two percentage points in crude protein in diets without supplementation of the three limiting amino acids is harmful to the birds.

In this study of 32-week-old birds, differences in the relative weights of yolk and albumen of the eggs from hens consuming different diets were not significant (Table 4). The shell percentages were affected, however. These data on the percentage of albumen corroborate those of Pavan et al. (2005), who worked with protein levels of 17.5, 16.5 and $15.5 \%$ on Isa Brown layers at 52 weeks of age. Similar results were also found by Umigi et al. (2012) with Japanese quails fed diets with crude protein reductions (22 to $17 \%$ ). However, in some studies the percentage of albumen is affected by reductions in the dietary crude protein. In an experiment with 43-week-old layers (Lohmann Brown), Costa et al. (2004) verified a decrease in the albumen content with decreased crude protein (17.5 to $15.5 \%$ ). Similar behaviour was observed by Silva et al. (2010), with protein reductions from 18 to $12 \%$ in the diet of layers (Hisex White) at 48 weeks of age.

Table 4. Percentage of yolk (PY), albumen (PA) and shell (PS) of eggs from white hens fed diets with levels of protein reduction and amino acid supplementation.

\begin{tabular}{lccc}
\hline \multicolumn{1}{c}{ Treatments } & PY (\%) & PA (\%) & PS (\%) \\
\hline $\mathrm{T}_{1}-16.02 \%$ CP + Met + Lys + Thr + Trp + Val & 25.5 & 64.6 & $10.0^{\mathrm{b}}$ \\
$\mathrm{T}_{2}-14.02 \%$ CP + Met + Lys + Thr + Trp + Ile + Val & 26.5 & 63.5 & $10.0^{\mathrm{b}}$ \\
$\mathrm{T}_{3}-14.02 \%$ CP - no supplementation of amino acids & 25.6 & 64.5 & $9.9^{\mathrm{b}}$ \\
$\mathrm{T}_{4}-14.02 \%$ CP + Met + Lys + Thr + Trp & 26.2 & 63.8 & $10.0^{\mathrm{b}}$ \\
$\mathrm{T}_{5}-14.02 \%$ CP + Met + Lys + Thr & 25.7 & 64.1 & $10.3^{\mathrm{ab}}$ \\
$\mathrm{T}_{6}-14.02 \%$ CP + Met & 26.7 & 63.0 & $10.3^{\mathrm{ab}}$ \\
$\mathrm{T}_{7}-14.02 \%$ CP + Lys & 26.8 & 62.4 & $10.8^{\mathrm{a}}$ \\
$\mathrm{T}_{8}-14.02 \%$ CP + Thr & 26.2 & 63.1 & $10.7^{\mathrm{a}}$ \\
$\mathrm{T}_{9}-14.02 \%$ CP + Trp & 26.5 & 62.9 & $10.6^{\mathrm{a}}$ \\
\hline Probability & 0.056 & 0.068 & 0.015 \\
\hline CV $(\%)$ & 3.56 & 1.53 & 2.91 \\
\hline $\mathrm{N}$ & 54 & 54 & 54 \\
\hline Mean & 26.19 & 63.54 & 10.29 \\
\hline STD & 0.486 & 0.760 & 0.341 \\
\hline
\end{tabular}

${ }^{\mathrm{a}, \mathrm{b}}$ Means followed by different lowercase letters in the column are significant by the SNK test; CV = coefficient of variation. Source of the author. N - Total number of data. STD - Standard deviation.

The divergence of the results concerning internal egg quality is due to a strong relationship of these variables with age, genetics, feeding and environmental conditions (UMIGI et al., 2012).
The proportions of egg components tend to remain constant, while losses stem from the temperature and time of storage (SCOTT; SILVERSIDES, 2000; ALLEONI; ANTUNES, 2001; JONES et al., 2002; 
GARCIA et al., 2010). In the present study eggs were evaluated fresh on the collection day.

The percentage of shell (Table 4) and specific gravity (Table 5) were affected by the different diets. However, shell thickness (Table 5) did not change, contradicting the data obtained for specific gravity, which are between 1.080 and $1.090 \mathrm{~g} / \mathrm{cm}^{3}$. Nevertheless, these data are within the normal range for layers (SILVA et al., 2006).

Table 5. Specific gravity (SG), shell thickness (ST), Haugh unit (HU) of eggs from white hens fed diets with levels of protein reduction and amino acid supplementation.

\begin{tabular}{lccc}
\hline \multicolumn{1}{c}{ Treatments } & $\begin{array}{c}\mathrm{SG} \\
\left(\mathrm{g} \mathrm{cm}^{3(-1)}\right)\end{array}$ & $\begin{array}{c}\mathrm{ST} \\
(\mathrm{mm})\end{array}$ & HU \\
\hline $\mathrm{T}_{1}-16.02 \%$ CP + Met + Lys + Thr + Trp + Val & $1.086^{\mathrm{abc}}$ & 0.39 & 96.0 \\
$\mathrm{~T}_{2}-14.02 \%$ CP + Met + Lys + Thr + Trp + Ile + Val & $1.087^{\mathrm{abc}}$ & 0.39 & 94.0 \\
$\mathrm{~T}_{3}-14.02 \%$ CP - no supplementation of amino acids & $1.085^{\mathrm{bc}}$ & 0.38 & 97.3 \\
$\mathrm{~T}_{4}-14.02 \%$ CP + Met + Lys + Thr + Trp & $1.084^{\mathrm{c}}$ & 0.39 & 96.6 \\
$\mathrm{~T}_{5}-14.02 \%$ CP + Met + Lys + Thr & $1.086^{\mathrm{abc}}$ & 0.39 & 98.8 \\
$\mathrm{~T}_{6}-14.02 \%$ CP + Met & $1.089^{\mathrm{ab}}$ & 0.40 & 98.3 \\
$\mathrm{~T}_{7}-14.02 \%$ CP + Lys & $1.089^{\mathrm{ab}}$ & 0.40 & 98.8 \\
$\mathrm{~T}_{8}-14.02 \% \mathrm{CP}+\mathrm{Thr}$ & $1.088^{\mathrm{ab}}$ & 0.39 & 98.2 \\
$\mathrm{~T}_{9}-14.02 \% \mathrm{CP}+\mathrm{Trp}$ & $1.089^{\mathrm{ab}}$ & 0.40 & 94.1 \\
\hline Probability & 0.006 & 0.433 & 0.008 \\
\hline CV $(\%)$ & 0.19 & 4.85 & 2.57 \\
\hline $\mathrm{N}$ & 54 & 54 & 54 \\
\hline Mean & 1.087 & 0.39 & 96.90 \\
\hline STD & 0.002 & 0.007 & 1.877 \\
\hline
\end{tabular}

${ }^{\mathrm{a}, \mathrm{b}}$ Means followed by different lowercase letters in the column are significant by the SNK test; CV = coefficient of variation. Source of the author. N - Total number of data. STD - Standard deviation.

Shell quality is related to the supply of calcium, phosphorus (SILVA et al., 2008), electrolytic balance (MURAKAMI et al., 2003; RIBEIRO et al., 2008) and lysine in the diet. These factors were corrected for in all diets, except for the amount of lysine, which could cause acidification. However, the electrolytic balance $(151.3 \mathrm{mEq} \mathrm{kg}$ $\left.{ }^{1}\right)$ was maintained for all diets. These values are below those determined by Ribeiro et al. (2008) and Murakami et al. (2003), of $174 \mathrm{mEq} \mathrm{kg}^{-1}$ and the recommendations of Rostagno et al. (2011), of $221.1 \mathrm{mEq} \mathrm{kg}^{-1}$. However, electrolytic balance can be better related to the shell data in experiments when the environmental conditions (especially heat stress) are also evaluated.
Regarding the Haugh unit, according to Kirunda and Mckee (2000), migration of water from the albumen to the yolk and low protein synthesis are factors that can decrease the Haugh unit values. However, the percentages of albumen were not significantly different (Table 4). This result was expected, as the loss of internal egg quality occurs during storage (SCOTT; SILVERSIDES, 2000; ALLEONI; ANTUNES, 2001; GARCIA et al., 2010), and in the present study the eggs were analysed on the collection day.

The values for nitrogen ingested, excreted and retained differed between the birds fed on the different diets (Table 6). Birds fed the control diet $\left(\mathrm{T}_{1}\right)$ ingested, excreted and retained more nitrogen. 
These birds consumed a diet with greater protein content $(16.02 \%)$ in relation to the other diets together (14.02\%), and the higher the intact protein content, the greater the nitrogen excretion (SILVA et al., 2010). This is due to the fact that birds ingested much more nitrogen $(43.16 \%)$ and excreted more (variation of $7.91 \%$ ) and retained more nitrogen (variation of $89.71 \%$ ) in relation to the average of all other treatments.

As to the other treatments $\left(\mathrm{T}_{2}, \mathrm{~T}_{3}, \mathrm{~T}_{4}, \mathrm{~T}_{5}, \mathrm{~T}_{6}, \mathrm{~T}_{7}\right.$, $\mathrm{T}_{8}$ and $\mathrm{T}_{9}$ ), as the amino acids were removed from the diets, the ingestion, retention and excretion decreased. The same was observed by Silva et al. (2010) for ingestion and retention. The results for nitrogen excretion corroborate those found by Pavan et al. (2005).

Table 6. Nitrogen ingested (NI), excreted (NE), retained (NR) and retained nitrogen percentage nitrogen (RNP) in the diets and excreta of white layers fed diets with levels of protein reduction and amino acid supplementation.

\begin{tabular}{|c|c|c|c|c|}
\hline Treatments & $\begin{array}{c}\text { NI } \\
(\%)\end{array}$ & $\begin{array}{l}\mathrm{NE} \\
(\%)\end{array}$ & $\begin{array}{l}\text { NR } \\
(\%)\end{array}$ & $\begin{array}{c}\text { RNP* } \\
(\%)\end{array}$ \\
\hline $\mathrm{T}_{1}-16.02 \% \mathrm{CP}+\mathrm{Met}+\mathrm{Lys}+\mathrm{Thr}+\mathrm{Trp}+\mathrm{Val}$ & $1.970^{\mathrm{a}}$ & $0.779^{\mathrm{a}}$ & $1.190^{\mathrm{a}}$ & 60.41 \\
\hline $\mathrm{T}_{2}-14.02 \% \mathrm{CP}+\mathrm{Met}+\mathrm{Lys}+\mathrm{Thr}+\mathrm{Trp}+\mathrm{Ile}+\mathrm{Val}$ & $1.490^{\mathrm{b}}$ & $0.764^{\mathrm{ab}}$ & $0.470^{\mathrm{e}}$ & 31.54 \\
\hline $\mathrm{T}_{3}-14.02 \% \mathrm{CP}-$ no supplementation of amino acids & $1.460^{\mathrm{b}}$ & $0.680^{\mathrm{d}}$ & $0.780^{\mathrm{b}}$ & 53.42 \\
\hline $\mathrm{T}_{4}-14.02 \% \mathrm{CP}+\mathrm{Met}+\mathrm{Lys}+\mathrm{Thr}+\operatorname{Trp}$ & $1.400^{\mathrm{c}}$ & $0.750^{\mathrm{b}}$ & $0.650^{\mathrm{c}}$ & 46.43 \\
\hline $\mathrm{T}_{5}-14.02 \% \mathrm{CP}+\mathrm{Met}+\mathrm{Lys}+\mathrm{Thr}$ & $1.380^{\mathrm{cd}}$ & $0.755^{\mathrm{b}}$ & $0.630^{\text {cd }}$ & 45.65 \\
\hline $\mathrm{T}_{6}-14.02 \% \mathrm{CP}+\mathrm{Met}$ & $1.380^{\mathrm{cd}}$ & $0.767^{\mathrm{ab}}$ & $0.610^{\text {cd }}$ & 44.20 \\
\hline $\mathrm{T}_{7}-14.02 \% \mathrm{CP}+$ Lys & $1.370^{\mathrm{cd}}$ & $0.753^{\mathrm{b}}$ & $0.610^{\text {cd }}$ & 44.53 \\
\hline $\mathrm{T}_{8}-14.02 \% \mathrm{CP}+\mathrm{Thr}$ & $1.340^{\mathrm{de}}$ & $0.679^{\mathrm{d}}$ & $0.660^{\mathrm{c}}$ & 49.25 \\
\hline $\mathrm{T}_{9}-14.02 \% \mathrm{CP}+\mathrm{Trp}$ & $1.320^{\mathrm{ef}}$ & $0.686^{\mathrm{d}}$ & $0.630^{\text {cd }}$ & 47.73 \\
\hline Probability & 0.001 & 0.004 & 0.003 & \multirow{5}{*}{---} \\
\hline CV $(\%)$ & 2.18 & 1.61 & 5.25 & \\
\hline $\mathrm{N}$ & 54 & 54 & 54 & \\
\hline Mean & 1.457 & 0.730 & 0.690 & \\
\hline STD & 0.200 & 0.041 & 0.203 & \\
\hline
\end{tabular}

${ }^{\mathrm{a}, \mathrm{b}}$ Means followed by different lowercase letters in the column are significant by the SNK test; CV $=$ coefficient of variation. $*$ Data not analyzed statistically. Source of the author. N - Total number of data. STD - Standard deviation.

The data on retention disagree with those observed by Silva et al. (2010), who found lower retention with higher dietary protein levels. However, this is due to the greater variation in the percentage of excreted nitrogen $(46.46 \%)$ between the basal diet and the average of the other treatments compared with that found in the present study (7.91\%). If we compare the control diet $(18.0 \%)$ with the $14 \%$ protein diet, excreted nitrogen was $40.8 \%$ (SILVA et al., 2010) still well above the percentage found in the present study $(7.91 \%)$.

\section{Conclusions}

Supplementation of methionine, lysine and threonine is essential for birds in the laying phase. However the addition of six essential amino acids (lysine, methionine, threonine, tryptophan, valine and isoleucine) to the diet of laying hens is important for a good productive performance comparable with the control treatment. However, the inclusion of the latter two (isoleucine and valine) is justified only if the production cost is lower. 


\section{References}

ALLEONI, A. C. C.; ANTUNES, A. J. Unidade haugh como medida da qualidade de ovos de galinha armazenados sob-refrigeração. Scientia Agricola, Piracicaba, v. 58, n. 4, p. 681-685, 2001.

BERTECHINI A. G. (Ed.). Nutrição de monogástricos. Lavras: Editora UFLA, 2006. 301 p.

COSTA, F. G. P.; SOUZA, H. C.; GOMES, C. A. V.; BARROS, L. R.; BRANDÃO, P. A.; NASCIMENTO, G. A. J.; SANTOS, A. W. R.; AMARANTE JUNIOR, V. S. Níveis de proteína bruta e energia metabolizável na produção e qualidade dos ovos de poedeiras da linhagem Lohmann Brown. Ciência e Agrotecnologia, Lavras, v. 28, n. 6, p. 1421-1427, 2004.

FARIA, D. E.; SANTOS, L. A. Nutritional requirements of layers. In: SIMPÓSIO INTERNACIONAL SOBRE EXIGÊNCIAS NUTRICIONAIS DE AVES E SUÍNOS, 2., 2005, Viçosa, MG. Anais... Viçosa, MG: Editora UFV, 2005. p. 145-157.

GARCIA, E. R. M.; ORLANDI, C. C. B.; OLIVEIRA, C. A. L.; CRUZ, F. K.; SANTOS, T. M. B.; OTUTUMI, L. K. Qualidade de ovos de poedeiras semipesadas armazenados em diferentes temperaturas e períodos de estocagem. Revista Brasileira de Saúde Produção Animal, Salvador, v. 11, n. 2, p. 505-518, abr. /jun. 2010.

HARPER, A. E.; BENEVENGA, N. J.; WOHLHUETER, R. M. Effects of ingestion of disproportionate amounts of amino acids. Physiological Reviews, Rockville Pike, v. 50, n. 3, p. 428-558, 1970.

JONES, D. R.; THARRINGTON, J. B.; CURTIS, P. A.; ANDERSON, K. E.; KEENER, K. M.; JONES, F. T. Effects of cryogenic cooling of shell eggs on egg quality. Poultry Science, Champaign, v. 8, n. 5, p. 727-733, 2002.

KERR, B. J.; EASTER, R. A. Effect of feeding reduced protein, amino acid-supplemented diets nitrogen and energy balance in grower pigs. Journal of Animal Science, Champaign, v. 73, n. 10, p. 3000-3008, 1995.

KIRUNDA, D. F. K.; MCKEE, S. R. Relating quality characteristic of aged eggs and fresh eggs to vitelline membrane strength as determined by a texture analyzer. Poultry Science, Champaign, v. 79, n. 8, p. 1189-1193, 2000.

LEESON, S.; SUMMERS J. D. (Ed.). Commercial poultry nutrition. Guelph: University Books, 1997. 350 p.

MAIA, A. S. C.; SILVA, R. G.; BASTTISTON LOREIRO, C. M. Sensible and latent heat loss from the body surface of Holstein cows in a tropical environment. International Journal of Biometeorology, Milwaukee, v. 50, n. 1, p. 17-22, 2005.
MATOS, M. B.; FERREIRA, R. A.; COUTO, H. P.; SAVARIS, V. D. L.; SOARES, R. T. R. N.; OLIVEIRA, N. T. E. Balanço eletrolítico da dieta e desempenho de frangos em condições naturais de estresse calórico. Arquivo Brasileiro de Medicina Veterinária e Zootecnia, Belo Horizonte, v. 63, n. 6, p. 1461-1469, 2011.

MENDONÇA JÚNIOR, C. X.; LIMA, F. R. Efeito dos níveis de proteína e de metionina da dieta sobre o desempenho de galinhas poedeiras após a muda forçada. Brazilian Journal of Veterinary Research and Animal Science, São Paulo, v. 36, n. 6, p. 332-338, 1999.

MURAKAMI, A. E.; FIGUEIREDO, D. F.; PERUZZI, A. Z.; FRANCO, J. R. G.; SAKAMOTO, M. I. Níveis de sódio para poedeiras comerciais no primeiro e segundo ciclos de produção. Revista Brasileira de Zootecnia, Viçosa, MG, v. 32, n. 6, p. 1674-1680, 2003.

PATTERSON, P. H.; ADRIZAL. Management strategies to reduce air emissions: emphasis-dust and ammonia. Journal of Applied Poultry Research, Athens, v. 14, n. 3, p. 638-650, 2005.

PAVAN, A. C.; MÓRI, C.; GARCIA, E. A.; SCHERER, M. R.; PIZZOLANTE, C. C. Níveis de proteína bruta e aminoácidos sulfurados totais sobre o desempenho, a qualidade dos ovos e a excreção de nitrogênio de poedeiras de ovos marrons. Revista Brasileira de Zootecnia, Viçosa, MG, v. 34, n. 2, p. 568-574, 2005.

RIBEIRO, M. L. G.; SILVA, J. H. V.; ARAÚJO, J. A.; MARTINS, T. D. D.; COSTA, F. G. P.; GIVISIEZ, P. E. N. Exigência de sódio para poedeiras no final do primeiro ciclo e durante o segundo ciclo de postura. Revista Brasileira de Zootecnia, Viçosa, MG, v. 37, n. 7, p. 1257 1264, 2008.

ROMBOLA, L. G.; RIZZO, M. F.; FARIA, D. E.; DEPONTI, B.; SIVA, F.; ARAÚJO, L. Alimentação de poedeiras com diferentes níveis de proteína e lisina: 1 . desempenho e qualidade dos ovos. In: CONFERÊNCIA APINCO DE CIÊNCIA E TECNOLOGIA AVÍCOLAS, 2004, Santos. Anais... Santos: 2004. p. 23.

ROSTAGNO, H. S.; ALBINO, L. F. T.; DONZELE, J. L.; GOMES, P. C.; OLIVEIRA, R. F.; LOPES, D. C.; FERREIRA, A. S.; BARRETO, S. L. T.; EUCLIDES, R. F. Tabelas brasileiras para aves e suinos: composição de alimentos e exigências nutricionais. 3. ed. Viçosa, MG: Universidade Federal de Viçosa, 2011. 252 p.

ROSTAGNO, H. S.; SILVA, D. S.; COSTA, P. M. A.; FONSECA, J. B.; SOARES, P. R.; PEREIRA, J. A. A.; SILVA, M. A. Tabelas brasileiras para aves e suinos: composição de alimentos e exigências nutricionais. Viçosa, MG: Universidade Federal de Viçosa, 2000. $186 \mathrm{p}$. 
SABINO, H. F. N.; SAKOMURA, N. K.; NEME, R.; FREITAS, E. R. Níveis proteicos na ração de frangos de corte na fase de crescimento. Pesquisa Agropecuária Brasileira, Brasília, v. 39, n. 5, p. 407-412, 2004.

SAKOMURA, N. K.; ROSTAGNO, H. S. Métodos de pesquisa em nutrição de monogástricos. Jaboticabal: Funep, 2007. 283 p.

SCOTT, T. A.; SILVERSIDES, F. G. The effect of storage and strain of hen on egg quality. Poultry Science, Champaign, v. 79, n. 12, p. 1725-1729, 2000.

SILVA, D. J.; QUEIROZ, A. C. Análises de alimentos: métodos químicos e biológicos. 2. ed. Viçosa, MG: Editora UFV, 2006. 235 p.

SILVA, E. L.; SILVA, J. H. V.; JORDAO FILHO, J.; RIBEIRO, M. L. G.; MARTINS, T. D. D.; COSTA, F. G. P. Redução dos níveis de proteína e suplementação de metionina e lisina em rações de poedeiras leves. Revista Brasileira de Zootecnia, Viçosa, MG, v. 35, n. 2, p. 491497, 2006.
SILVA, J. V.; ARAÚJO, J. A.; GOULART, C. C.; COSTA, F. G. P.; SAKOMURA, N. K.; MARTINS, T. D. D. Relação cálcio:fósforo disponível e níveis de fitase para poedeiras semipesadas no primeiro e segundo ciclos de postura. Revista Brasileira de Zootecnia. Viçosa, MG, v. 37, n. 12, p. 2166-2172, 2008.

SILVA, M. F. R.; FARIA, D. E.; RIZZOLI, P. W.; SANTOS, A. L.; SAKOMOTO, M. I.; SOUZA, H. R. B. Desempenho, qualidade dos ovos e balanço de nitrogênio de poedeiras comerciais alimentadas com rações contendo diferentes níveis de proteína bruta e lisina. Revista Brasileira de Zootecnia, Viçosa, MG, v. 39, n. 6, p. 1280-1285, 2010.

TINOCO, I. F. F. A granja de frangos de corte. In: MENDES, A. A.; NASS, I. A.; MACARI, M. (Ed.). Produção de frangos de corte. Campinas: FACTA, 2004. p. 55-84.

UMIGI, R. T.; BARRETO, S. L. T.; REIS, R. S.; MESQUITA FILHO, R. M.; ARAÚJO, M. S. Níveis de treonina digestível para codorna japonesa na fase de produção. Arquivo Brasileiro de Medicina Veterinária e Zootecnia, Belo Horizonte, v. 64, n. 3, p. 658-664, 2012. 